\title{
Correction to: Assessing species number and genetic diversity of the Mountainsnails (Oreohelicidae)
}

\author{
T. Mason Linscott ${ }^{1,2}\left(\right.$ Kathleen Weaver $^{3} \cdot$ Vanessa Morales $^{4} \cdot$ Christine E. Parent $^{1,2}$
}

Published online: 5 October 2020

(c) Springer Nature B.V. 2020

\section{Correction to: Conservation Genetics https://doi.org/10.1007/s10592-020-01302-5}

The original version of this article unfortunately contained several mistakes.

Please note the following corrections in the original article.

Under the heading "DNA sequencing, genotyping, and dataset composition", in third paragraph, the sentence that reads as "The combined 861 sequence dataset contained representatives of $60.9 \%$ (52 species) of all currently recognized species and subspecies in Oreohelicidae" should read as "The combined 861 sequence dataset contained representatives of $60.9 \%$ (50 species) of all currently recognized species and subspecies in Oreohelicidae".

Under the heading "Introduction", In fourth paragraph, the sentence that reads as "The Mountainsnails (family: Oreohelicidae) are a calciphilous family of montane-endemic land snails that includes two genera: Radiocentrum and Oreohelix-purportedly the most diverse genus of land snails in North America (82 currently recognized taxonomic species and subspecies; Pilsbry 1939; Nekola 2014)" should read as "The Mountainsnails (family: Oreohelicidae) are a calciphilous family of montane-endemic land snails that includes two genera: Radiocentrum and Oreohelix-purportedly the most

The original article can be found online at https://doi.org/10.1007/ s10592-020-01302-5.

T. Mason Linscott

mason.linscott@gmail.com

1 Department of Biological Sciences, University of Idaho, Moscow, ID, USA

2 Institute for Bioinformatics and Evolutionary Studies (IBEST), Biological Sciences, Moscow, ID, USA

3 Office of the Provost, Loyola Marymount University, Los Angeles, CA, USA

4 Office of Grant Evaluation and Statistical Support, Loyola Marymount University, Los Angeles, CA, USA diverse genus of land snails in North America (77 currently recognized taxonomic species and subspecies; Pilsbry 1939; Nekola 2014)".

Under the heading "Results", in third paragraph, the sentence that reads as "Using the criteria that a delimited species is threatened if all the previous taxonomic units that constitute the new delimited species are listed as NatureServe rank G2 or higher, we found 11 threatened species using these two approaches (Supplemental Table 1)" should read as "Using the criteria that a delimited species is threatened if all the previous taxonomic units that constitute the new delimited species are listed as NatureServe rank G2 or higher, we found 13 threatened species using these two approaches (Supplemental Table 1)".

In the original publication of the article, the Acknowledgements section was published incorrectly. The correct Acknowledgements section is given in this correction.

Acknowledgements We are grateful to Joel Sauder, Kate Holcomb, Jeff Sorenson, Samantha Ferguson, and Christina Sato for facilitating permits and providing logistic support while conducting fieldwork in Idaho, Utah, Arizona, New Mexico, and Washington, respectively. This work would not have been possible without the diligent collections or information provided by a number of academic and public field personnel: Lusha Tronstad, Paul Hendricks, Tom Burke, Hillary Boyd, Bill Gaines, Ann Sprague, Judy Hoder, Janet Millar, Eric Wagner, and Kevin Wheeler. Special thanks are given to Mark A. Ports for several stimulating discussions and providing a number of samples from the state of Nevada. We would also like to acknowledge the support of Heather Robeson and the University of Colorado Museum of Natural History for providing samples. Additional collection samples were provided by John Slapcinsky and the University of Florida Museum of Natural History. We are grateful to John Phillips, Kelly Martin, and Nicole Recla for comments on an earlier version of the manuscript. This work was funded by an an NSF Graduate Research Fellowship program award to T. Mason Linscott (NSF 1842399) and awards from the National Geographic Society, Washington Forest Service Interagency Special Status/Sensitive Species Program, and South Dakota Fish and Wildlife to Kathleen Weaver. Research reported in this publication was also supported by an Institutional Development Award 
(IDeA) from the National Institute of General Medical Sciences of the National Institutes of Health under grant number P30 GM103324 to Larry J. Forney.
Publisher's Note Springer Nature remains neutral with regard to jurisdictional claims in published maps and institutional affiliations. 